\title{
PENERAPAN METODE PERBANDINGAN EKSPONENSIAL (MPE) DALAM SISTEM PENDUKUNG KEPUTUSAN PENERIMA BEASISWA SISWA BERPRESTASI PADA SMK XYZ
}

\author{
Page $\mid 17$ \\ Rohmat Indra Borman ${ }^{1}$, Fauzi Helmi ${ }^{2}$ \\ ${ }^{12}$ Fakultas Teknik dan Ilmu Komputer (FTIK), Universitas Teknokrat Indonesia \\ Jl. Z. A. Pagar Alam No.9 -11, Labuhan Ratu, Kedaton, Kota Bandar Lampung, Lampung, 35132, Indonesia \\ ${ }^{1}$ rohmat_indra@teknokrat.ac.id, ${ }^{2}$ fauzihelmi@gmail.com
}

\begin{abstract}
Abstrak - Beasiswa siswa berprestasi merupakan beasiswa pemberian penghargaan terhadapa siswa yang memiliki prestasi dalam belajar.Penerima bantuan siswa berprestasi pada SMK XYZ terdapat beberapa kriteria yang di tentukan seperti prestasi, kedisiplinan, kehadiran. Proses seleksi melalui Tata Usaha merekap data siswa kemudian dijadikan bahan rapat antara guru dan wali kelas.Hal ini membutuhkan kejelian yang tinggi dalam penentuanya.Sistem pendukung keputusan menawarkan kemudahan dalam pengambilan keputusan.Sistem pendukung keputusan dapat diartikan sebagai sistem informasi interaktif yang menyediakan informasi, pemodelan dan manipulasi data.Untuk mengatasi kriteria yang majemuk pada pengambilan keputusan maka pada penelitian ini menggunakan Metode Perbandingan Eksponensial (MPE).MPE dapat mengurangi bias yang mungkin terjadi dalam analisis, karena nilai skor yang dihasilkan mengambarkan urutan prioritas yang menjadi besar sehingga urutan prioritas alternatif keputusan menjadi lebih nyata. Pada penelitian ini menghasilkan sistem pendukung keputusan untuk menetukan penerima beasiswa siswa berprestasi dengan kriteria prestasi, kedisiplinan, kehadiran dengan menerapkan metode MPE.
\end{abstract}

Kata kunci - Metode Perbandingan Eksponensial (MPE).

\section{PENDAHULUAN}

Bantuan siswa berprestasi merupakan bantuan biaya pendidikan, berbeda dari beasiswa yang berfokus pada pemberian penghargaan atau dukungan dana terhadap mereka yang memiliki keterbatasan ekonomi, bantuan siswa berprestasi berfokus kepada yang memiliki prestasi dalam belajar. Dalam proses penentuan penerima bantuan siswa berprestasi ada beberapa kriteria yang di tentukan oleh pihak sekolah seperti prestasi, kedisiplinan, kehadiran. Proses yang dilakukan dalam seleksi dimulai dari Tata Usaha merekap kriteria-kriteria yang telah ditentukan kemudian dijadikan bahan rapat antara guru dan wali kelas dan diusulkan ke Kepala Sekolah untuk menetapkansiswa yang layak mendapatkan beasiswa prestasi. Hal ini membutuhkan kejelian dari Tata Usaha dalam merekap data siswa berdasarkan prestasi yang diperoleh, kedisiplinan dalam mentaati aturan sekolah, tingkat kehadiran dari semua siswa kemudian data tesebut akan digunakan untuk calon penerima beasiswa berprestasi. Penentuan dan penetapan penerimaan beasiswa berdasarkan hasil rekap data yang dilakukan oleh Tata Usaha. Tidak ada perhitungan khusus dan pembobotan setiap kriteria untuk menentukan penerima beasiswa siswa berprestasi.Untuk itu dibutuhkan sistem pendukung keputusan, sehingga keputusan yang diperoleh dapat lebih akurat.

Sistem pendukung keputusan meruakan sebuah sistem yang di maksudkan untuk mendukung para pengambil keputusan manajerial dalam situasi tertentu[1]. Sistem pendukung keputusan dapat diartikan juga sebagai sistem informasi interaktif yang menyediakan informasi, pemodelan dan manipulasi data[2]. Pengambilan keputusan dapat dipengaruhi oleh beberapa aspek, dikarenakan dalam pengambilan keputusan permasalahan yang diselesaikan kompleks dan kriteria yang digunakan majemuk. Salah satu metode pengambilan keputusan yang digunakan untuk kriteria yang majemuk adalah Metode Perbandingan Eksponensial (MPE). Metode Perbandingan Eksponensial (MPE) merupakan metode yang di gunakan untuk menentukan urutan prioritas alternatif keputusan dengan kriteria jamak[3]. MPE dapat mengurangi bias yang mungkin terjadi dalam analisis, karena nilai skor yang dihasilkan mengambarkan urutanprioritas yang menjadi besar sehingga urutan prioritas alternatif keputusan menjadi lebih nyata[4]. Pada penelitian ini akan menerapkan MPE dalam membantu pengmbil keputusan untuk menetukan penerima beasiswa siswa berprestasi dengan kriteria prestasi, kedisiplinan, kehadiran.

\section{TINJAUAN PUSTAKA}

\section{A. Sistem Pendukung Keputusan}

Pengambilan keputusan dapat diartikan sebagai proses pemilihan alternatif terbaik dari beberapa alternatif secara sistematis untuk ditindaklanjuti (digunakan) sebagai suatu cara pemecahan masalah[5]. Dalam pengambilan keputusan organisasi dapat memanfaatkan teknologi yang ada atau melalui sistem tertentu.Sistem tersebut disebut 
sebagai sistem pendukung keputusan. Sistem pendukung keputusan merupakan program komputer yang menyediakan informasi dalam domain aplikasi yang diberikan oleh suatu model analisis keputusan dan akses ke database, dimana hal ini ditujukan untuk mendukung pembuat keputusan (decision maker) dalam mengambil keputusan secara efektif baik dalam kondisi yang kompleks dan tidak terstruktur[6]. Sistem pendukung keputusan digunakan untuk membantu bagi para pengambil keputusan namun tidak untuk menggantikan penilaian pengambil keputusan.Komponen sistem pendukung keputusan teridiri dari beberapa subsistem, diantaranya subsistem manajemen data, subsistem manajemen model, subsistem antar muka pengguna dan subsistem manajemen berbasis pengetahuan[7]. Berikut ini adalah penjelasana dari subsistemsubsistem tersebut :

1. Subsistem Manajemen Data

Pada subsistem manajemen data berhubungan erat dengan penyimpanan data.Subsistem manajemen data mencakup satu database yang berisi data yang relevan untuk situasi dan dikelola oleh sistem manajemen basisdata (Data Base Management Systems).

2. Subsistem Manajemen Model

Pada subsistem ini berisi paket perangkat lunak yang memasukkan model keuangan, statistik, ilmu manajemen, atau model kuantitatif lainnya yang memberikan kapabilitas analitik dan manajemen perangkat lunak yang tepat.

3. Subsistem Manajemen Antar Muka

Subsistem ini menangani komunikasi antara pengguna dan sistem pendukung keputusan.Pengguna adalah bagian yang dipertimbangkan dari sistem.

4. Subsistem Manajemen Berbasis Pengetahuan Subsistem ini mendukung semua subsistem yang ada selain itu juga bertindak sebagai komponen independen.Subsistem ini memberikan inteligensi untuk memperbesar pengetahuan pengambil keputusan.

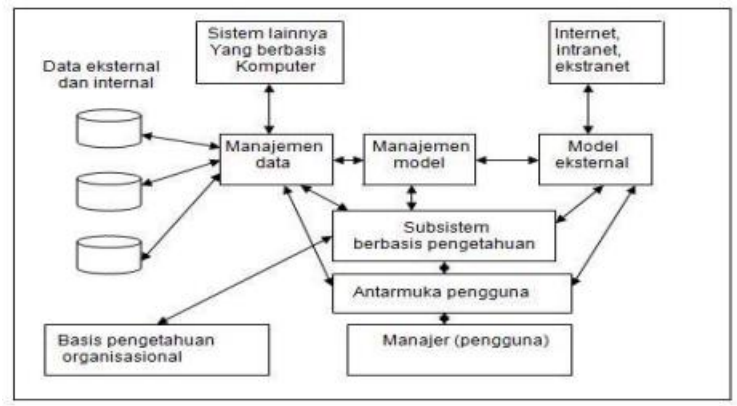

Gbr. 1 Komponen Sistem Pendukung Keputusan

Sistem Pendukung Keputusan menyediakan dukungan bagi pengambil keputusan utamanya pada situasi semi terstruktur dan tak terstruktur dengan memadukan pertimbangan manusia dan informasi terkomputerisasi.Berbagai masalah tak dapat diselesaikan (atau tak dapat diselesaikan secara memuaskan) oleh sistem terkomputerisasi lain, seperti EDP atau MIS tidak juga dengan metode atau tool kuantitatif standard[8]. Dukungan disediakan untuk berbagai level manajerial yang berbeda, mulai dari pimpinan puncak sampai manajer lapangan.

\section{B. Metode Perbandingan Eksponensial (MPE)}

Metode Perbandingan Exponensial (MPE) adalah salah satu metode dari Decision Suport System (DSS) yang digunakan untuk menentukan urutan prioritas alternatif keputusan dengan kriteria jamak[9]. Dengan perhitungan secara eksponensial, perbedaan nilai antara kriteria dapat dibedakan tergantung kepada kemampuan orang yang menilai[10]. Selain itu MPE merupakan salah satu metode pengambilan keputusan yang mengkuantifikasikan pendapat seseorang atau lebih dalam skala tertentu[11]. Teknik ini digunakan untuk membantu individu pengambil keputusan untuk menggunakan rancang bangun model yang terdefinisi dengan baik pada tahapan proses. MPE akan menghasilkan nilai alternatif yang perbedaannya lebih kontras.

Uuntuk menggunakan metode MPE terdapat beberpa langkah. Berikut ini adalah langkah-langkah yang perlu dilakukan dalam pemilihan keputusan dengan menggunakan MPE adalah:

1. Menyusun alternatif-alternatif keputusan yang akan dipilih.

2. Menentukan kriteria atau perbandingan relatif kriteria keputusan yang penting untuk di evaluasi dengan menggunkan skala konversi tertentu sesuai dengan keinginan pengambil keputusan.

3. Menentukan tingkat kepentingan relatif dari setiap kriteria keputusan atau pertimbangan kriteria. Penentuan bobot di tetapkan pada setiap kriteria untuk menunjukan tingkat kepentingan suatu kriteria.

4. Melakukan penilaian terhadap semua alternatif pada tiap kriteria dalam bentuk total skor tiap alternatif.

5. Menghitung skor atau nilai total setiap alternatif dan mengurutkannya. Semakin besar Total Nilai (TN) alternatif maka semakin tinggi urutan prioritasnya.Formulasi penghitungan Metode Perbandingan Eksponensial:

Total Nilai $\left(T N_{i}\right)=\sum_{j=1}^{m}\left(R K_{i j}\right)^{T K K_{j}}$

Keterangan:

$\begin{array}{ll}\mathrm{TNi} & =\text { Total nilai alternatif ke-i } \\ \mathrm{RKij} & = \\ & \text { Derajat kepentingan relatif } \\ & \text { kriteria ke-j pada } \\ & \text { pilihankeputusan ke-i } \\ = & \text { Derajat kepentingan kriteria } \\ & \text { keputusan ke-j TKKJ }>0 ; \text { bulat }\end{array}$




$$
\begin{array}{ll}
\mathrm{n} & =\text { Jumlah pilihan keputusan } \\
\mathrm{m} & =\text { Jumlah kriteria keputusan }
\end{array}
$$

\section{METODE PENELITIAN}

Page | 19

\section{A. Pengumpulan Data}

Teknik pengumulan data yang digunakan dala penelitian ini adalah wawancara. Wawancara merupakan teknik pengumpulan data yang dilakukan melalui tatap muka dan tanya jawab langsung antara pengumpul data maupun peneliti terhadap nara sumber atau sumber data. Wawancara dilakukan dengan narasumber staff Tata Usaha, Guru, Wali Kelas dan Kepala Sekolah pada SMK XYZ. Data yang diperoleh antara lain data proses pemilihan beasiswa siswa berprestasi mulai dari kriteria penerima, sub kriteria, nilai setiap kriteria dan bobot kriteria.

\section{B. Analisa Sistem}

Pada tahapan ini akan dilakukan analisa kebutuhan kebutuhan untuk mengetahui kebutuhan-kebutuhan dalam melakukan pengembangan sistem. Pada analisa kebutuhan terdapat analisa kebutuhan fungsional dan analisa kebutuhan non-fungsional.

1. Kebutuhan Fungsional

Kebutuhan fungsional menjelaskan tentang proses-proses apa saja yang nantinya dapat dilakukan oleh sistem. Berikut ini adalah kebutuhan fungsional penerapan MPE untuk penentuan siswa penerima beasiswa siswa berprestasi :

a) Sistem mampu memproses penilaian data siswa penerima bantuan siswa berprestasi.

b) Sistem mampu memberikan rekomendasi kelayakan secara objectif.

c) Sistem menghasilkan laporan data siswa penerima bantuan siswa berprestasidengan efisien dan efektif.

\section{Kebutuhan Non Fungsional}

Kebutuhan yang menitik beratkan pada properti prilaku yang dimiliki oleh sistem. Berikut ini adalah kebutuhan non-fungsional dari sistem yang akan dikembangkan:

a) Kebutuhan Software

Sistem Operasi Microsoft Windows 7, Adobe

Dreamweaver Cs 5, Database MySQL dan Browser (Mozilla Firefox, Internet Explorer dll)

b) Kebutuhan Hardware

Processor Dual Core, Ram DDR 22 GB, Hardisk $250 \mathrm{~Gb}$ dan Printer

\section{Perancangan dan Pemodelan}

Perancangan sistem melibatkan identifikasi dan deskripsi abstraksi sistem perangkat lunak yang mendasar dan hubungan-hubungannya. Pada penelitian ini menggunakan use case diagram dalam pemodelan dan perancangan. Use case diagram menggambarkan fungsional yang diharapkan dari sebuah sistem. Sebuah use case mempresentasikan sebuah interaksi antara actor dengan sistem. Use case diagram dari sistem yang akan dikembangkan dapat dilihat pada gambar 2 .

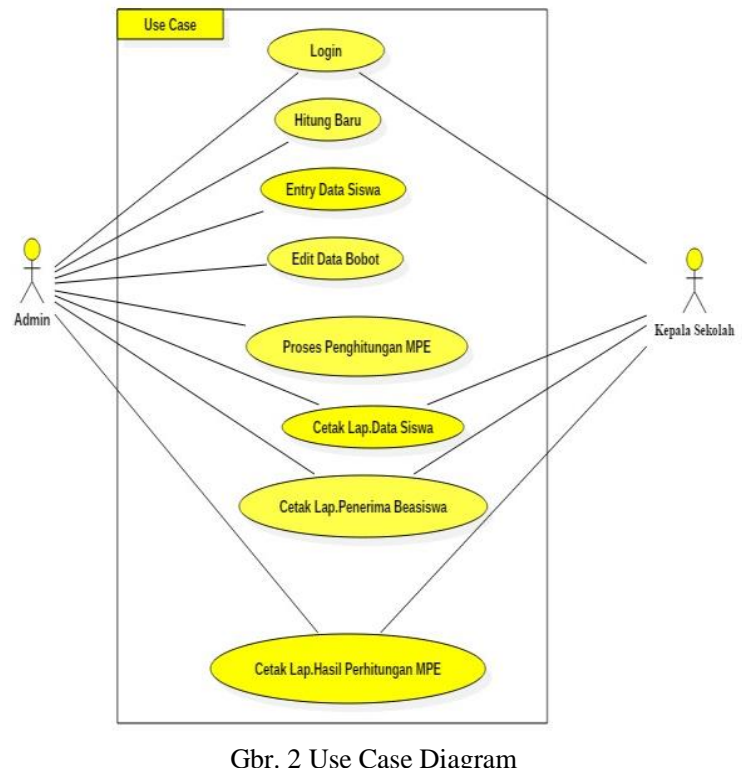

D. Impelementasi Sistem

Pada tahapan implementasi sistem akan dilakukan penerapan sistem yang termasuk pada pembuatan program berdasarkan pada tahap perancangan dan alaisa yang telah ditetapkanuntuk dapat diterapkan. Pada penelitian ini metode perbandingan exsponensial (MPE) akan diimplementasikan kedalam bahasa pemrograman PHP dengan databasi MySQL untuk menghasilkan sebua aplikasi sistem pendukung keputusan penentuan beasiswa siswa berprestasi.

\section{HASIL DAN PEMBAHASAN}

Uuntuk menerapkan MPE pada sistem pendukung keputusan terdapat beberpa langkah.

A. Menyusun alternatif-alternatif keputusan yang akan dipilih.

Misalkan terdapat tiga alternatif yang berpotensi untuk mendapatkan beasiswa, berikut ini adalah daftar alternatif yang akan ditentukan untuk mendapatkan beasiswa siswa berprestasi :

1. Adhita Ramadhan

Mempunyai profil alternatif :

Kriteria Prestas

a. Nilai Raport 85

b. Sertifikat Prestasi $=$ Ada

Kedisiplinan

a. Mematuhi Peraturan = Mematuhi

b. $\quad$ Datang Tepat Waktu $=$ Tepat Waktu

c. Mengikuti Pelajaran $=$ Mengikuti Pelajaran

Kehadiran

a. $\quad$ Absensi $=$ Selalu Hadir

2. Ahmad Fajri

Mempunyai profil alternatif : 
Kriteria Prestasi

a. Nilai Raport 70

b. Sertifikat Prestasi $=$ Ada

Kedisiplinan

a. Mematuhi Peraturan $=$ Tidak Patuh

b. Datang Tepat Waktu = Tepat Waktu

Page | 20 Kehadiran

a. Absensi = Jarang Hadir

3. Agnes Adinda Permata

Mempunyai profil alternatif :

Kriteria Prestasi

a. Nilai Raport 80

b. $\quad$ Sertifikat Prestasi $=$ Tidak Ada

Kedisiplinan

a. Mematuhi Peraturan $=$ Patuh

b. Datang Tepat Waktu $=$ Tepat Waktu

c. Mengikuti Pelajaran $=$ Mengikuti Pelajaran

Kehadiran

a. Absensi $=$ Jarang Hadir

B. Menentukan kriteria atau perbandingan relatif kriteria keputusan yang penting untuk di evaluasi

Kriteri yang akan digunakan dalam sistem pendukung keputusan untuk penentuan penerima beasiswa siswa berprestasi berdasarkan pengumpulan data dengan wawancara kepada pengambil keputusan pada SMK KYZ. Dari hasil wawancara didaptkan tabel I, yang berisi tentang kretieria dan sub kriteria yang telah ditentukan oleh pegambil keputusan.

TABEL I

KRITERIA PENERIMA BEASISWA SISWA BERPRESTASI

\begin{tabular}{|c|c|c|}
\hline Kriteria & \multicolumn{2}{|c|}{ Sub Kriteria } \\
\hline \multirow[t]{5}{*}{ Prestasi } & \multirow{3}{*}{ Nilai Raport } & $90-100$ \\
\hline & & $80-90$ \\
\hline & & $\leq 80$ \\
\hline & \multirow{2}{*}{ Sertifikat } & Ada \\
\hline & & Tidak Ada \\
\hline \multirow[t]{6}{*}{ Kedisiplinan } & \multirow{2}{*}{$\begin{array}{l}\text { Mematuhi } \\
\text { Peraturan } \\
\text { Sekolah }\end{array}$} & Patuh \\
\hline & & Tidak Patuh \\
\hline & \multirow{2}{*}{$\begin{array}{l}\text { Datang } \\
\text { Tepat Waktu }\end{array}$} & Tepat Waktu \\
\hline & & Sering Terlambat \\
\hline & \multirow{2}{*}{$\begin{array}{l}\text { Mengikuti } \\
\text { Pelajaran } \\
\text { Sekolah }\end{array}$} & $\begin{array}{l}\text { Mengikuti } \\
\text { Pelajaran }\end{array}$ \\
\hline & & $\begin{array}{l}\text { Tidak } \\
\text { Mengikuti } \\
\text { Pelajaran }\end{array}$ \\
\hline
\end{tabular}

\begin{tabular}{|c|l|l|}
\hline Kriteria & \multicolumn{2}{|c|}{ Sub Kriteria } \\
\hline Kehadiran & \multirow{2}{*}{ Absensi } & Selalu Hadir \\
\cline { 3 - 3 } & & Jarang Hadir \\
\hline
\end{tabular}

C. Menentukan tingkat kepentingan relatif dari setiap kriteria keputusan atau pertimbangan kriteria.

Pada tahapan ini akan ditentukan penentuan bobot pada setiap kriteria untuk menunjukan tingkat kepentingan suatu kriteria. Bobot yang akan digunakan dalam sistem pendukung keputusan untuk penentuan penerima beasiswa siswa berprestasi berdasarkan pengumpulan data dengan wawancara kepada pengambil keputusan pada SMK KYZ. Dari hasil wawancara didaptkan tabel II, yang berisi nilai masing masing sub kriteria danbobot dari setiap kriteria yang telah ditentukan oleh pegambil keputusan.

TABEL III

TINGKAT KEPENTINGAN DARI SETIAP KRITERIA

\begin{tabular}{|c|c|c|c|c|}
\hline Kriteria & \multicolumn{2}{|c|}{ Sub Kriteria } & Nilai & Bob \\
\hline \multirow[t]{5}{*}{ Prestasi } & \multirow{3}{*}{ Nilai Raport } & $90-100$ & 3 & 3 \\
\hline & & $80-90$ & 2 & \\
\hline & & $\leq 80$ & 1 & \\
\hline & \multirow{2}{*}{ Sertifikat } & Ada & 2 & \\
\hline & & Tidak Ada & 1 & \\
\hline \multirow{6}{*}{$\begin{array}{l}\text { Kedisiplin } \\
\text { an }\end{array}$} & \multirow{2}{*}{$\begin{array}{l}\text { Mematuhi } \\
\text { Peraturan } \\
\text { Sekolah }\end{array}$} & Patuh & 2 & 2 \\
\hline & & Tidak Patuh & 1 & \\
\hline & \multirow{2}{*}{$\begin{array}{l}\text { Datang } \\
\text { Tepat } \\
\text { Waktu }\end{array}$} & $\begin{array}{l}\text { Tepat } \\
\text { Waktu }\end{array}$ & 2 & \\
\hline & & $\begin{array}{l}\text { Sering } \\
\text { Terlambat }\end{array}$ & 1 & \\
\hline & \multirow{2}{*}{$\begin{array}{l}\text { Mengikuti } \\
\text { Pelajaran } \\
\text { Sekolah }\end{array}$} & $\begin{array}{l}\text { Mengikuti } \\
\text { Pelajaran }\end{array}$ & 2 & \\
\hline & & $\begin{array}{l}\text { Tidak } \\
\text { Mengikuti } \\
\text { Pelajaran }\end{array}$ & 1 & \\
\hline \multirow[t]{2}{*}{ Kehadiran } & \multirow[b]{2}{*}{ Absensi } & Selalu Hadir & 2 & 1 \\
\hline & & $\begin{array}{l}\text { Jarang } \\
\text { Hadir }\end{array}$ & 1 & \\
\hline
\end{tabular}

D. Melakukan penilaian terhadap semua alternatif pada tiap kriteria dalam bentuk total skor tiap alternatif.

Dari kasus alternatif yang telah ditentukan sebelumnya berikutnya adalah mengkonversi nilai 
profil alternatif kedalam nilai yang telah ditentukan oleh pengambil keputusan pada tabel II.Hasil konversi nilai dapat dilihat pada tabel III.

TABEL IIIII

KONVERSI NILAI ALTERNATIF

Page | 21

\begin{tabular}{|c|c|c|c|c|}
\hline Nama & Kriteria & & Kriteria & Nilai \\
\hline & Prestasi & $\begin{array}{l}\text { Nilai } \\
\text { Raport }\end{array}$ & 85 & 3 \\
\hline & Sertifikat & Sertifikat & Ada & 2 \\
\hline & & $\begin{array}{l}\text { Mematuhi } \\
\text { Peraturan } \\
\text { Sekolah }\end{array}$ & Patuh & 2 \\
\hline $\begin{array}{l}\text { Ramadh } \\
\text { an }\end{array}$ & $\begin{array}{l}\text { Kedisiplina } \\
\mathrm{n}\end{array}$ & $\begin{array}{l}\text { Datang } \\
\text { Tepat } \\
\text { Waktu }\end{array}$ & Tepat Waktu & 2 \\
\hline & & $\begin{array}{l}\text { Mengikuti } \\
\text { Pelajaran } \\
\text { Sekolah }\end{array}$ & $\begin{array}{l}\text { Mengikuti } \\
\text { Pelajaran }\end{array}$ & 2 \\
\hline & Kehadiran & Absensi & Selalu Hadir & 2 \\
\hline & Prestasi & $\begin{array}{l}\text { Nilai } \\
\text { Raport }\end{array}$ & 80 & 2 \\
\hline & Sertifikat & Sertifikat & Ada & 2 \\
\hline & & $\begin{array}{l}\text { Mematuhi } \\
\text { Peraturan } \\
\text { Sekolah }\end{array}$ & Patuh & 2 \\
\hline $\begin{array}{l}\text { Ahmad } \\
\text { Fajri }\end{array}$ & $\begin{array}{l}\text { Kedisiplina } \\
\mathrm{n}\end{array}$ & $\begin{array}{l}\text { Datang } \\
\text { Tepat } \\
\text { Waktu }\end{array}$ & Tepat Waktu & 2 \\
\hline & & $\begin{array}{l}\text { Mengikuti } \\
\text { Pelajaran } \\
\text { Sekolah }\end{array}$ & $\begin{array}{l}\text { Mengikuti } \\
\text { Pelajaran }\end{array}$ & 2 \\
\hline & Kehadiran & Absensi & Jarang Hadir & 1 \\
\hline & Prestasi & $\begin{array}{l}\text { Nilai } \\
\text { Raport }\end{array}$ & 80 & 2 \\
\hline & Sertifikat & Sertifikat & Tidak Ada & 1 \\
\hline & & $\begin{array}{l}\text { Mematuhi } \\
\text { Peraturan } \\
\text { Sekolah }\end{array}$ & Patuh & 2 \\
\hline $\begin{array}{l}\text { Adinda } \\
\text { Permata }\end{array}$ & $\begin{array}{l}\text { Kedisiplina } \\
\mathrm{n}\end{array}$ & $\begin{array}{l}\text { Datang } \\
\text { Tepat } \\
\text { Waktu }\end{array}$ & Tepat Waktu & 2 \\
\hline & & $\begin{array}{l}\text { Mengikuti } \\
\text { Pelajaran } \\
\text { Sekolah }\end{array}$ & $\begin{array}{c}\text { Mengikuti } \\
\text { Pelajaran }\end{array}$ & 2 \\
\hline & Kehadiran & Absensi & Jarang Hadir & 1 \\
\hline
\end{tabular}

E. Menghitung skor atau nilai total setiap alternatif dan mengurutkannya.

Langkah selanjutnya adalah menghitung skor atau nilai total setiap alternatif dan mengurutkannya.
Semakin besar Total Nilai (TN) alternatif maka semakin tinggi urutan prioritasnya.

Total Nilai $\left(T N_{i}\right)=\sum_{j=1}^{m}\left(R K_{i j}\right)^{T K K_{j}}$

Derajat kepentingan setiap kriteria yang telah ditentukan oleh pngambil keputusan adalah kriteria prestasi $=3$, kriteria kedisiplinan $=2$, kriteria kehadiran $=1$.

Total Nilai untuk Adhita Ramadhan :

$$
\begin{aligned}
\mathrm{TN}_{1} & =\left(3^{\wedge} 3\right)+\left(2^{\wedge} 3\right)+\left(2^{\wedge} 2\right)+\left(2^{\wedge} 2\right)+\left(2^{\wedge} 2\right)+\left(2^{\wedge} 1\right) \\
& =27+8+4+4+4+2 \\
& =49
\end{aligned}
$$

Total Nilai untuk Ahmad Fajri

$$
\begin{aligned}
\mathrm{TN}_{2} & =\left(2^{\wedge} 3\right)+\left(2^{\wedge} 3\right)+\left(2^{\wedge} 2\right)+\left(2^{\wedge} 2\right)+\left(2^{\wedge} 2\right)+\left(1^{\wedge} 1\right) \\
& =8+8+4+4+4+1 \\
& =29
\end{aligned}
$$

Total Nilai untuk Agnes Adinda Permata :

$$
\begin{aligned}
\mathrm{TN}_{3} & =\left(2^{\wedge} 3\right)+\left(1^{\wedge} 3\right)+\left(2^{\wedge} 2\right)+\left(2^{\wedge} 2\right)+\left(2^{\wedge} 2\right)+\left(2^{\wedge} 1\right) \\
& =8+3+4+4+4+2 \\
& =25
\end{aligned}
$$

Dari total nilai tersebut didapatkan Adhita Ramadhan adalah alternatif terbaik utnuk memperoleh beasiswa berprestasi dengan nilai total tertinggi.

Selanjutnya penerapan MPE pada sistem pendukung keputusan penentuan penerima beasiswa siswa berprestasi pada SMK XYZ diimplementasikan pada bahasa pemrograman PHP dengan menggunakan database MySQL. Gbr. 2 menenujukan menu input data siswa yang kan menjadi alternatif untuk dipilih dalam penentuan mahasiswa siswa berprestasi.

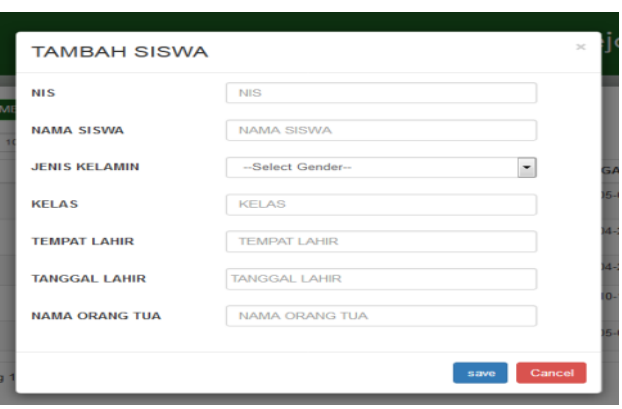

Gbr. 2 Form Tambah Data

Setelah data siswa diinputkan berikutnya adalah memberikan penilaian terhadap siswa tersebut dengan MPE.Gbr. 3 menunjukan menu penilain MPE untuk menentukan penerima beasiswa siswa berprestasi.

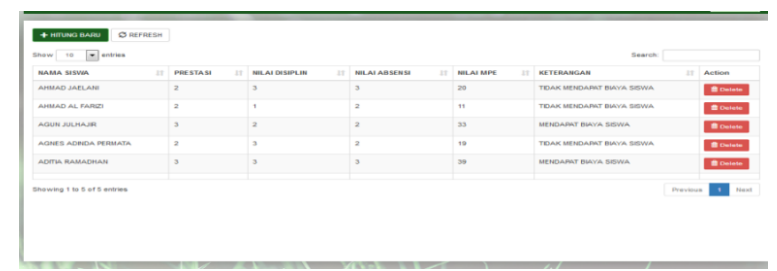

Gbr. 3 Form Penilaian MPE 
Etelah didapatkan hasil penerima siswa berprestasi, pengmbil keputusan dapat mencetak laporan hasil penerima beasiswa siswa berprestasi pada laporan data beasiswa yang terlihat seperti pada Gbr. 4 .

Page | 22

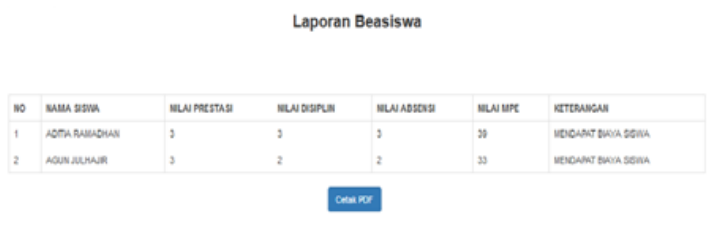

Gbr. 4 Laporan hasil beasiswa

\section{KESIMPULANDAN SARAN}

A. Kesimpulan

Berdasarkan penelitian yang telah dilakukan dapat disimpulkan seagai berikut :

1. Untuk menerapkan metode perbandingan exsponensial (MPE) pada sistem pendukung keputusan penerima beasiswa siswa berprestasi terdapat beberapa tahapan diantaranya menyusun alternatif-alternatif keputusan yang akan dipilih, menentukan kriteria, menentukan tingkat kepentingan relatif dari setiap kriteria keputusan, penentuan bobot di tetapkan pada setiap kriteria, melakukan penilaian terhadap semua alternatif pada tiap kriteria dalam bentuk total skor tiap alternatif.

2. Pada penerapan MPE hasil alternatif akan ditentukan dari total nilai yang didapatkan dari penjumlahan konversi nilai setiap kriteria dan sub kriteria kemudian dipangkatkan dengan tingkat kepentingan setiap kriteria (bobot) yang telah ditentukan pengambil keputusan.

\section{B. Saran}

Adapu beberapa saran yang dapat dilakukan untuk penelitian selanjutnya untuk perbaikan penelitian yang telah dilakukan antara lain :

1. Pada penentuan konversi nilai dan penentuan prioritas kreiteria menemukan permasalahan ketidak pastian, dikarenakan tidak semua kriteria dapat ditentukan nilainya secara tegas maka dari itu penelitian selanjutnya dapat mengembangkan dengan menggunakan metode fuzzy logic.

2. Dalam penelitian ini belum terdapat akses untuk siswa kedalam sistem, sehingga diharapkan untuk penelitian lebih lanjut sistem ini dapat di akses oleh siswa agar siswa dapat mendapatkan informasi yang dibutuhkan..

\section{REFERENSI}

[1] E. Turban, E. J. Aronson, and Ting-Peng Liang, Decision Support Systems and Intelligent Sistems (Sistem Pendukung Keputusan dan Sistem Cerdas) Jilid 2 Edisi 7. Yogyakarta: Andi Publisher, 2007.

[2] Kusrini, Konsep Dan Aplikasi Sistem Pendukung Keputusan. Yogyakarta: Andi Publisher, 2007.

[3] A. Wibowo and A. S. Honggowibowo, "Sistem Pendukung Keputusan Untuk Menentukan Lokasi Peternakan Ayam
Broiler Dengan Metode Perbandingan Eksponensial Dan Naive Bayes," COMPILER, Vol. 3, Nomor 2, November 2014.

[4] A. H. Rangkuti, "Teknik Pengambilan Keputusan Multi Kriteria Menggunakan Metode Bayes, MPE, CPI dan AHP," ComTech, Vol.2 No. 1, Juni 2011.

[5] L. H. Siagian, H. Mawengkang, and Z. Situmorang, "Sistem Penunjang Keputusan Pemberian Kredit Menggunakan Logika Fuzzy Pada Dealer Sepeda Motor Honda," CESS (Journal of Computer Engineering System and Science), Vol. 2 No. 2, Juli 2017

[6] Burhanuddin and Dini, "Sistem Pendukung Keputusan Dalam Pemberian Beasiswa Dengan Menggunakan Metode Weighted Product," CESS (Journal of Computer Engineering System and Science), Vol. 2 No. 2, Juli 2017.

[7] E. Turban, E. J. Aronson, and TP. Liang, Decision Support Systems and Intelligent Sistems (Sistem Pendukung Keputusan dan Sistem Cerdas) Jilid 1 Edisi 7. Yogyakarta: Andi Publisher, 2005.

[8] S.Y. Prayogi, "Penerapan Metode Simple Additive Weighting Dalam Pemilihan Tablet PC Untuk Pemula," CESS (Journal Of Computer Engineering, System And Science), Vol 1, No 1 , Januari 2016, Januari 2016.

[9] Marimin, Konsep dan Aplikasi Sistem Pendukung Keputusan Yogyakarta: Andi Publisher, 2007.

[10] Heny Pratiwi, Buku Ajar Sistem Pendukung Keputusan. Yogyakarta: Deepublish.

[11] E.Yulianti and F. Juwita, "Sistem Pendukung Keputusan Pemilihan Tempat Kuliner Di Kota Padang Menggunakan Metode Perbandingan Eksponensial (MPE)," TEKNOIF, Vol 4 No. 2, Oktober 2016. 